\title{
REFLETIR SOBRE IMAGENS EM COMUNIDADES REMANESCENTES DE QUILOMBO DA AMAZÔNIA BRASILEIRA
}

\author{
Marcilene Silva da Costa ${ }^{1}$
}

\section{Introdução}

A decisão de trabalhar com imagens na pesquisa em comunidades rurais surgiu da intenção de ir além das convenções metodológicas tradicionais embora consciente que produção e circulação de imagens sejam parte integrantes da pratica antropológica desde o inicio da disciplina, mas como bem lembrou Becker (2001) na antropologia praticada antigamente, as imagens mais corriqueiras eram as fotografias consideradas até então como uma obrigação a mais do trabalho de campo e que serviam geralmente para ilustrar a vida em sociedade.

$\mathrm{Na}$ antropologia contemporânea além desse uso convencional as imagens passaram a ser consideradas muito mais como fonte de conhecimento o que lhes leva a ocupar um lugar tão importante quanto o da escritura gráfica no texto antropológico na medida em que oferecem elementos de reflexão tanto do contexto em que foram produzidas quanto tentativas de compreensão das sociedades estudadas. Dessa forma, assim como a produção escrita, as imagens podem ser consideradas como uma interpretação da sociedade estudada. No entanto, ao longo do texto procurarei deixar explícito que as considerações acima foram elaboradas após leitura da literatura sobre o assunto (Laplantine, 2007; Marques, 2006) bem depois da realização do trabalho de campo durante o qual ver imagens produzidas por mim e pelos interlocutores da pesquisa tinham apenas um sentido, o de interação entre nós.

Esse artigo se baseia em trabalho de campo realizado, de forma fragmentada de 2002 à 2011, em duas comunidades rurais, Macapazinho e Boa Vista do Itá, localizadas no município de Santa Isabel do Pará, região norte, Amazônia, Brasil. Em 1988, habitantes das duas localidades obtiveram informações de que poderiam recuperar terras, que venderam ou perderam para os fazendeiros dos arredores, se inscrevendo no processo de reivindicação de terras coletivas como comunidades remanescentes de quilombo (Silva da Costa, 2011).

\footnotetext{
${ }^{1}$ Universidade de Toulouse II - Jean Jaurès, França.
} 
Macapazinho conseguiu regularizar parte das terras que reivindicava como quilombola, em maio de 2008, após dez anos de espera. Porém, o mesmo não aconteceu com Boa Vista do Itá, o processo de regularização de terras dessa comunidade se encontra paralisado desde outubro de 2008.

\section{Tão perto, tão longe e os imponderáveis de lidar com "nativos" tão próximos do meu quintal. A África é aqui mesmo.}

[...] o campo te obriga na antropologia, é uma coisa meio complicada. Eu não faço o que quero, eu faço o que posso. Várias pessoas vão ao campo tentar ver uma coisa e veem outra e são obrigadas a estudar aquela. (Amaral apud Silva, 2000: 31)

A lembrança mais antiga que tenho de Macapazinho, um dos vilarejos onde fiz meu trabalho de campo, remonta minha infância, precisamente os domingos ensolarados quando minha família costumava frequentar o balneário Caraparu que se localiza nos arredores da cidade onde nasci.

O percurso que fazíamos de ônibus para chegar ao balneário passava pelo povoado. Dessa forma nesse ponto do trajeto que deveria durar uns três minutos os passageiros costumavam por a cabeça para fora da janela do ônibus para olhar com curiosidade e atenção os habitantes de Macapazinho sentados embaixo das árvores em frente às suas casas. Então, era nesse momento que um adulto sussurrava em meu ouvido : - é aqui que moram os "pretos da África”, olha só como são feios e têm cara de desconfiados! Eu também botava minha cabeça para fora e ficava olhando até vê-los ficar pequeninos e desaparecer completamente na paisagem. Nessa época a palavra quilombola estava bem longe do meu vocabulário infantil e também do vocabulário dos moradores de Macapazinho que eram conhecidos pelos citadinos apenas como africanos.

Já adulta e estudante do mestrado em antropologia elaborei um projeto de estudo sobre construção da identidade quilombola e realizei pesquisa de campo na África da minha infância considerada depois da promulgação da constituição de 1988 como um quilombo contemporâneo.

Diferentemente de Malinowski (1989) meu campo não era longínquo, tampouco, tinha praias desertas, e assim seguindo a "boa e velha tradição" antropológica brasileira, eu estudei o meu "quintal", ou, em outras palavras, a minha 
própria sociedade. Não precisei ir a outro continente para me deparar com o "exótico" que no meu imaginário infantil me era "familiar".

No entanto, esses "outros" representantes da "alteridade" que pensava estarem próximos a mim, pelo menos geograficamente, a menos de 30 quilômetros de casa e também no meu imaginário, ao contrário, estavam bem longe e a aproximação se fez a duras penas visto que nossos "universos de compreensão" não se cruzavam. As inquietações sobre se adquiriria uma postura objetiva ou subjetiva indo ao encontro desses "nativos" foram acalmadas com a leitura das obras de Gilberto Velho (1980, 1978), esse antropólogo afirma que a distância geográfica que irá percorrer o pesquisador em direção ao grupo que irá estudar não é garantia de objetividade e isenção.

Cursei o mestrado no período de 2002 à 2004, e fiz meu trabalho de campo em Macapazinho ao longo dos anos 2002 e 2003. O trabalho de campo em Macapazinho resultou na dissertação sobre o lugar, onde analisei construção/reconstrução de identidades tendo como fio condutor a memória social de seus habitantes e também suas relações com representantes do Movimento Negro urbano e funcionários de órgãos do governo, os chamados agentes mediadores.

É importante sublinhar que quando comecei o Mestrado, não pensava em estudar produção/construção de identidades, isso foi algo que se delineou em campo, por estar, não só latente, mas se fazer presente, nas conversas com as pessoas, nas observações que fiz e nas conversas com antropólogos e historiadores especialistas no assunto, que na época ministravam disciplinas no Mestrado.

Ao iniciar trabalho do campo em Macapazinho, pensei em estudar os saberes dos habitantes mais antigos que não foram adquiridos na escola, no ensino formal, relacionando-os com as memórias desses. Tratava-se de um estudo sobre a "ciência do concreto" dos anciãos da comunidade, utilizando como referencial teórico basicamente Lévi-Strauss (1962) e Geertz (1998).

Porém, outro tema se evidenciava nas conversas, nas observações que fiz como algo importante de estudar dado o perfil da comunidade - população predominantemente negra vivendo em meio rural. E não só isso, mas o momento que os moradores de Macapazinho estavam vivendo era específico, eles estavam reivindicando legalização das terras que habitavam baseados no artigo 68 do Ato das Disposições Constitucionais Transitórias (ADCT) da constituição brasileira de 1988 que declara: 
"[a]os remanescentes das comunidades dos quilombos que estejam ocupando suas terras é reconhecida a propriedade definitiva, devendo o Estado emitir-lhes os respectivos títulos" 2 .

Os vários embates, tanto internos como externos, para a legalização das terras se tornavam mais evidentes conforme eu adentrava no "universo" da comunidade. A todo instante algum morador me lembrava que lá era uma comunidade "remanescente de quilombo" e que eles eram quilombolas com direito à terra. A identidade quilombola emergia ao mesmo tempo em que decorria o processo pela legalização das terras. Não só em Macapazinho, mas, geralmente, em outras localidades, que passavam pelo mesmo processo. Esse fenômeno Arruti (2006) já tinha observado no decorrer de suas pesquisas.

Aliás, desde a primeira visita à Macapazinho em conversa com o presidente da associação local, ele enfatizou que eram "descendentes de quilombolas e que lutavam pela legalização das terras" e para legitimar o que dizia me mostrou o relatório antropológico do lugar dizendo que ali se encontrava "a história de Macapazinho" 3. Ora, como já enfatizaram alguns críticos da disciplina (Caratini, 2012; Clifford, 2002), a grande parte dos "nativos" dos grupos ou sociedades estudados hoje em dia, já sabem ler e escrever e interessam-se pelos livros que lhes descrevem, os leem e os reinterpretam, reapropriando-se dos escritos sobre si tornando assim cada vez mais evidente o fato que os antropólogos são responsáveis em validar a singularidade e alteridade dos grupos que pesquisam.

Para realização do doutorado (2008-2015) mudei de país e universidade, em busca de ampliar minha formação científico- profissional, porém, continuei explorando a temática dos quilombos para tentar responder a pistas de pesquisa que ficaram abertas durante o mestrado já que durante esse tinha trabalhado basicamente com a (re)construção de identidades. Para o doutorado decidi direcionar o foco da pesquisa sobre o impacto que irá causar o artigo 68 na vida de habitantes não só de Macapazinho, mas também de outra localidade, Boa Vista do Itá, que decidiu acionar o referido artigo para conseguir o direito à terra. Sendo assim, busquei compreender até que ponto a

\footnotetext{
${ }^{2}$ Cf. Constituição Federal, 1988. Brasília: Senado Federal, p.169.

3 Trata-se do relatório antropológico de NOGUEIRA, Shirley e TRINDADE, Joseline 2000. Macapazinho: história e memória dos negros do Itá. Projeto: Comunidades rurais negras do Pará, Belém. O trabalho fez parte do Projeto Comunidades Negras Rurais do Pará que resulta de um convênio entre o Núcleo de Altos Estudos Amazônicos (NAEA) da UFPA, a entidade do Movimento Negro : Centro de Estudos e Defesa do Negro do Pará (CEDENPA) e o governo do Estado. O projeto iniciou em 1998.
} 
aplicação de políticas multiculturais mudou as subjetividades, mobilidades da categoria raça/cor em populações que aceitaram o rótulo quilombola já que a questão da cor da pele e aparência representa um elemento essencial na construção política da problemática quilombola ligada a posse da terra como domínio coletivo visto que a referência aos traços físicos e origem estão imbricadas na qual a cor aparece como signo forte de pertencimento (Silva da Costa, 2015).

\section{O retorno ao "campo" e a "salvação" pelas fotografias}

Retornei à Macapazinho em junho de 2009, exatamente um ano após eles terem obtido o título coletivo da terra e dois anos depois da minha última visita. No primeiro dia "da volta" ainda na cidade enquanto esperava o ônibus que me levaria até lá, reconheci, sentada no ponto de ônibus uma jovem que segurava uma criança no colo. Era a filha de uma informante. Quando ela me viu, gritou para a moça que lhe acompanhava: - olha, a menina que escreveu o livro sobre Macapazinho. Tu lembras dela? O que a outra respondeu positivamente. Então, as duas ficaram entorno de mim e uma delas falou que algumas pessoas comentavam na localidade que eu tinha escrito o livro sobre o lugar e depois tinha sumido.

Meu retorno foi tratado com euforia por alguns e desdém por muitos. A situação se assemelhava a que vivenciei durante a oficina que elaborei, em 2006, no povoado para mostrar por meio de uma apresentação PowerPoint ilustrada com fotos de lá os resultados da pesquisa do mestrado. Tentei utilizar uma linguagem acessível e didática o que despertou o interesse dos poucos adultos presentes que perguntavam querendo saber mais sobre a pesquisa. Uma das participantes declarou que tinha gostado da linguagem empregada que achou de "fácil entendimento". Mas, na verdade, a presença massiva na oficina foi de crianças e alguns idosos. Os jovens e adultos apareceram somente no horário de distribuição do lanche. Declararam que o jogo de voleibol, as músicas e a cerveja do barzinho eram mais atrativos que notícias e documentários sobre "pretos", mesmo se tratando deles mesmos.

Durante minha estada em campo em 2009, alguns moradores insistentemente perguntavam: no que a antropologia poderia ajudá-los em termos financeiros. Depois de me conceder entrevista, o presidente da associação local, me pediu que conseguisse com políticos municipais, bolas e redes de voleibol para continuarem praticando o esporte. 
Afirmou que na concepção local, uma pessoa "de fora", seja ela um pesquisador ou agente de governo que chega à comunidade sem conduzir um automóvel, não possui nem poder, nem prestígio. Eu não possuía nenhum dos dois porque utilizava o ônibus como transporte. Então, na sua lógica, o que eu fazia não traria benefícios explícitos para eles. Tal fato foi se atenuando conforme foram se acostumando com minha presença ou, até mesmo, ignorando-a.

É preciso que fique claro que não fui eu a antropóloga que elaborou o já mencionado relatório antropológico do lugar, peça importante para obtenção do titulo coletivo da terra. Ele foi elaborado pela historiadora Shirley Nogueira e pela antropóloga Joseline Trindade no ano de 2000. Dessa forma, eu não gozava do status de "antropólogo que ajudou a obter o título da terra" ${ }^{4}$. Se a maioria dos estudos sobre as comunidades remanescentes de quilombos surge no contexto de reconhecimento oficial e da reivindicação do direito à terra e como desdobramento do laudo antropológico, não era o caso da minha pesquisa, eu era apenas vista, por muitos, como uma "moça entrevistadeira" que gostava de perguntar e andar embaixo do "sol quente" para lá e para cá. Dessa forma, da privilegiada posição etnográfica de quem elabora o laudo não pude usufruir, os dados não chegavam a mim, eu tinha que "correr" atrás deles, o que, no entanto, abriu um novo campo de interação e observação. Ao longo dos anos minha presença foi marcada pelo rótulo de " a mulher que gostava de conversar e tirar fotos".

Algumas vezes, quando estava fazendo recenseamento ou registrando entrevista com o sol a pino, alguns me lançavam olhares de compaixão, e um certo dia uma senhora declarou: "nessa profissão vocês devem sofrer muito". Provava o mesmo desolamento que Barley (2001) na sua experiência de campo com os Dowayo, do Norte de Camarões, em África. Porém, não precisei me transformar em motorista de táxi, nem em enfermeira como o pesquisador fez junto aos Dowayo. Encontrei meu lugar como «fotógrafa oficial», sendo assim, registrava os eventos que aconteciam na comunidade e cedia cópias das fotografias a eles, o que custava um relativo gasto financeiro visto que registrava aniversários, jogos, eventos religiosos, entre outros.

Mencionei tais acontecimentos para mostrar como as fotografias facilitaram a socialização com os interlocutores da pesquisa tanto em Macapazinho quanto em Boa Vista do Itá. Nos povoados nenhum morador possui máquina fotográfica e é rara a oportunidade que têm de se verem fotografados e de terem acesso a uma imagem de si.

\footnotetext{
${ }^{4}$ Nos povoados que reivindicam o título da terra como quilombolas acionando o "artigo 68 " a figura do antropólogo está fortemente associada à fabricação da peça técnica, o laudo antropológico.
} 
Em cada um dos retorno em campo eu levava cópias das fotografias tiradas. Dessa forma, a devolução das fotografias permitia maior interação em campo. No entanto, as fotografias não foram feitas apenas com esse objetivo.

Sabe-se que em antropologia a imagem pode servir de suporte a escritura e vice-versa visto que da mesma forma que o texto escrito traduz e interpreta a imagem também pode fazer isso. John Collier Junior (1973), antropólogo americano, um dos pioneiros a publicar um livro sobre o uso da fotografia como método na antropologia, explica que, as fotografias feitas em campo sinalizam uma área rica de pesquisa nãoverbal e quando minuciosamente observadas poderão revelar dimensões complexas da vida social de um grupo. Para ele, a curiosidade de ver o próprio retrato ou a imagem do meio em que se vive, dificilmente falha para se obter um convite para ir e mostrar a fotografia. Durante uma entrevista, uma imagem também pode ter a função de estimular a memória e proporcionar um caráter de proximidade com os informantes.

Considero as fotografias feitas no decorrer do trabalho de campo como uma das atividades de observação in loco. Destarte, elaborei o que considero, tomando emprestado a expressão de Conord (2007), um "diário de campo visual" de onde da mesma maneira que do caderno de campo utilizei as informações ao longo da escrita da tese. Ao todo fiz em torno de novecentas fotografias, entre retrato de pessoas, paisagens e cenas da vida cotidiana.

Em Boa Vista, na memória local consta referências ao senhor de escravos, Major dos Santos, antigo proprietário das terras onde habitam. Sendo assim, nas narrativas dos habitantes de Boa Vista estão presentes referências ao lugar de origem do Major dos Santos, que teria imigrado de Mazagão, em África, com seus escravos para o local onde se situa atualmente a comunidade. Mazagão era um pequeno vilarejo fortificado, de domínio português, banhado pelo oceano Atlântico, localizado no norte da África, no Marrocos, foi restaurada e rebatizada, em 1832 como El Jadida, pelo sultão Moulay Abderrahman. Visitei Mazagão em 2009, ocasião em que fiz fotos do lugar para mostrar aos interlocutores da pesquisa. Ao ver as fotos eles ficaram fascinados e discutiram animadamente por ser a primeira vez que viam um Marrocos que não foi mostrado na telenovela $O$ Clone da Rede Globo. Na ocasião pude observar e anotar os diálogos que tiveram estimulados pelas fotografias de Mazagão. 
Uma das primeiras visitas que fiz a Macapazinho foi na festa do produtor rural do município de Santa Izabel que acontece a cada ano em uma localidade diferente. Em 2002 Macapazinho é que tinha sido escolhida. No decorrer da festa houve uma briga envolvendo um citadino e habitantes do lugar. O desfecho foi trágico: o citadino armado de um revólver feriu várias pessoas, entre adultos e crianças e por fim assassinou um morador de Boa Vista, o marido de uma das informantes da pesquisa, Arlinda.

Semanas após a festa, retornei ao povoado com cópias de fotos que fiz durante o evento, para que os moradores pudessem vê-las. Assim que cheguei, as pessoas me olharam com certa desconfiança - quase sempre dispensada aos de fora - porém, minutos depois, conversando com alguns moradores, que jogavam dominó, mostrei as fotos, para alegria das crianças e dos adultos presentes que se aglomeraram em volta de mim. Uma senhora que inicialmente parecia a mais arredia, pediu para ver as fotos sozinha e com calma, e logo depois se mostrou relaxada e disposta a conversar. Outra mulher, Rosa Simith que raras vezes se viu retratada disse que ia urgentemente providenciar um quadro, para colocar uma das fotografias na parede da sala. A devolução das fotografias proporcionou um momento de descontração e abriu um campo de diálogo. O fato de ter feito, sem querer, uma foto do carro do assassino deixou as pessoas eufóricas e de repente todos falavam ao mesmo tempo dando opinião sobre o trágico evento. Tal acontecimento mostra como discursos podem ser provocados a partir das fotografias.

No papel de fotógrafa pude observar e registrar diversas formas de socialização, lazer, trabalho e outras cenas do cotidiano. Houve, no geral, dois quadros em que as fotos foram produzidas: o primeiro, fotografias que foram feitas a pedido dos informantes que me chamavam e pediam para serem retratados sozinhos ou acompanhados onde faziam "caras e bocas" se divertindo diante da câmera fotográfica, em momentos de trabalho ou lazer. E no segundo quadro, elas foram efetuadas de acordo com minhas escolhas do que considerava importante ou interessante fotografar.

No entanto, mesmo se as fotografias criassem quase instantaneamente um clima de cordialidade e proximidade com os informantes. Houve dois momentos em que se passou exatamente o contrário. Na primeira incursão à Boa Vista em agosto de 2009 acompanhada de uma estudante de direito, nos primeiros dias decidimos explorar toda área da comunidade e acabamos conhecendo as roças limítrofes às fazendas. Durante esse percurso encontramos uma senhora que trabalhava como diarista em uma 
das roças e ela nos convidou à acompanhá-la para nos apresentar aos outros trabalhadores. A primeira pessoa a quem ela nos apresentou foi ao dono da roça, um rapaz jovem, que nos explicou que decidiu contratar oito moradores locais para auxiliálo no plantio da mandioca. Ele trabalha a noite em uma empresa de Frango e graças ao salário que ganha pode pagar as diárias de dez reais por dia a cada trabalhador. As pessoas capinavam e conversavam animadamente, contavam piadas e gargalhavam. Pedimos permissão ${ }^{5}$ para fazer fotos deles enquanto trabalhavam. Havia quatro mulheres e quatro homens. Nesse momento, reinou um silêncio e por fim um homem respondeu que aceitaria sem problemas, mas eram as mulheres e não ele que deveriam autorizar. Eis que uma delas respondeu que aceitariam apenas serem filmadas e não fotografadas. Deu-nos as costas, ignorando-nos, visivelmente irritada. Pedimos desculpas e partimos. Porém, ao mesmo tempo em que propiciou clima tenso, o episódio da "permissão da fotografia" permitiu o primeiro contato com esse grupo de pessoas. Isto é, mesmo se em tom de recusa, os primeiros diálogos estabelecidos com esses moradores foram gerados a partir das fotos.

Se no primeiro evento houve apenas intenção, no segundo o uso da câmera fotográfica foi completamente inapropriado no decorrer de uma oficina, em janeiro de 2011, sobre capacitação de técnicas do plantio da mandioca ministrada por uma equipe de agrônomos da Embrapa aos moradores de Macapazinho. Eles solicitaram o curso à agência de pesquisa devido as dificuldades encontradas na colheita da mandioca, muitas roças estavam produzindo mandioca podre inapropriadas ao consumo. O curso ocorreu na roça de um dos moradores. Onde os engenheiros agrônomos explicavam e os moradores desenvolviam na prática todas as etapas do cultivo da mandioca enfocando as fases de estabelecimento da cultura, tratos culturais, controle de pragas e doenças, manejo da colheita e da pós-colheita. O calcário e adubo para trato do solo foi fornecido pela EMBRAPA. São produtos que eles raramente têm acesso devido a não terem dinheiro para comprar. A oficina durou dois dias, e fotografei todas as etapas, no final do segundo dia, acabei registrando sem querer uma cena inoportuna para algumas pessoas e também para mim. Posicionei a câmera e comecei a fazer fotos meio distraída, quando de repente, algumas pessoas me olharam assustadas e envergonhadas, foi então que percebi que elas estavam guardando para si vários sacos de adubos. Virei

\footnotetext{
${ }^{5}$ Em campo, o procedimento era pedir um autorização oral da pessoa antes dela ser retratada.
} 
rapidamente, apaguei as fotos e guardei a máquina tão constrangida quanto elas. Foi aí que percebi que há registros que devem ser evitados.

Com o passar do tempo fiquei conhecida como aquela que retratava e devolvia os retratos às pessoas fotografadas (ver fotografias 1 e 2). $O$ clima durante a restituição dos retratos era, em geral, de euforia, alegria e gerava comentários como: “- olha, fulano que é feio, nem tá tão preto assim, parece até bonito ou então: - nossa comunidade que é feia na fotografia está bonita". Segundo Novaes (2005), as imagens não falam por si, mas expressam e dialogam com modos de vida típicos da sociedade em que vivemos; como a imagem do negro no Brasil está, geralmente, relacionada ao que é feio, ruim, carregando consigo estereótipos negativos. Por meio das fotografias, os moradores dos povoados puderam se perceber, esteticamente, de forma positiva, emitindo opiniões sobre a beleza das gentes fotografadas ou até mesmo dos encantos do próprio lugar. Dessa forma, eu como pesquisadora me inseria na vida deles, sendo também responsável na construção da imagem e memória que faziam de si e do lugar onde habitam.

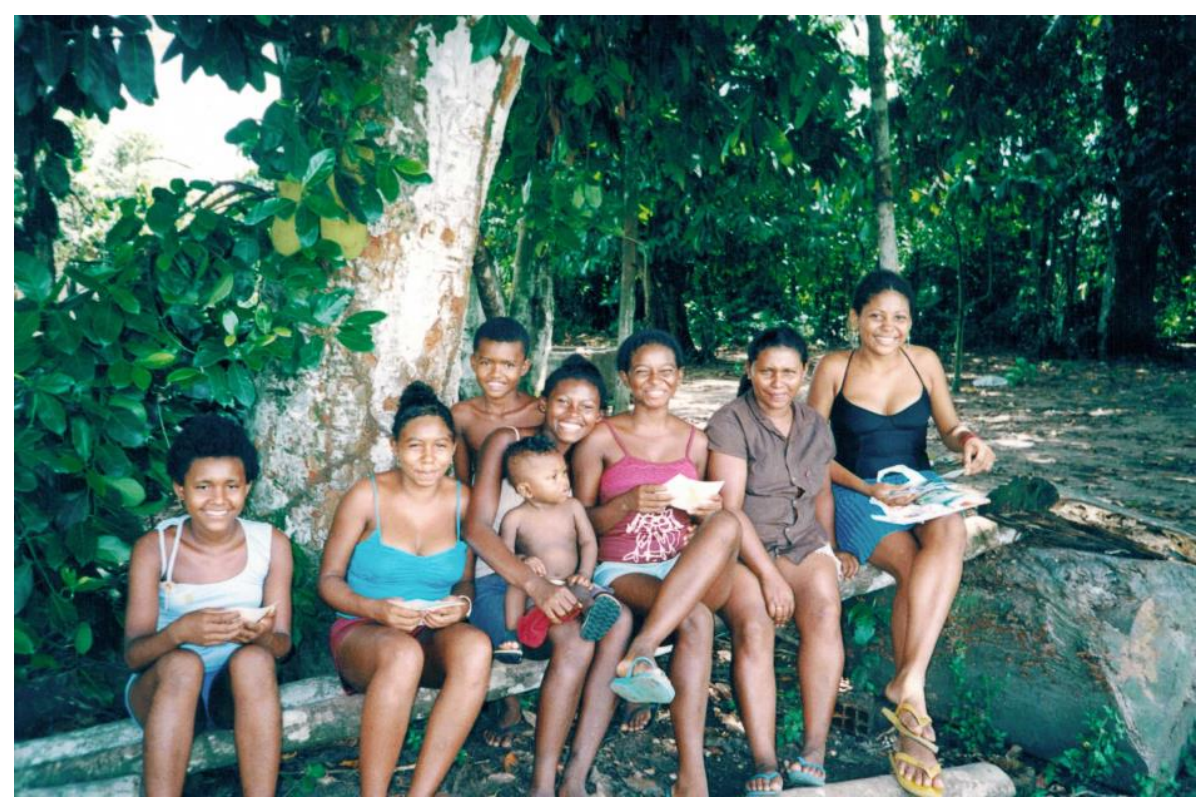

Fotografia 1. 


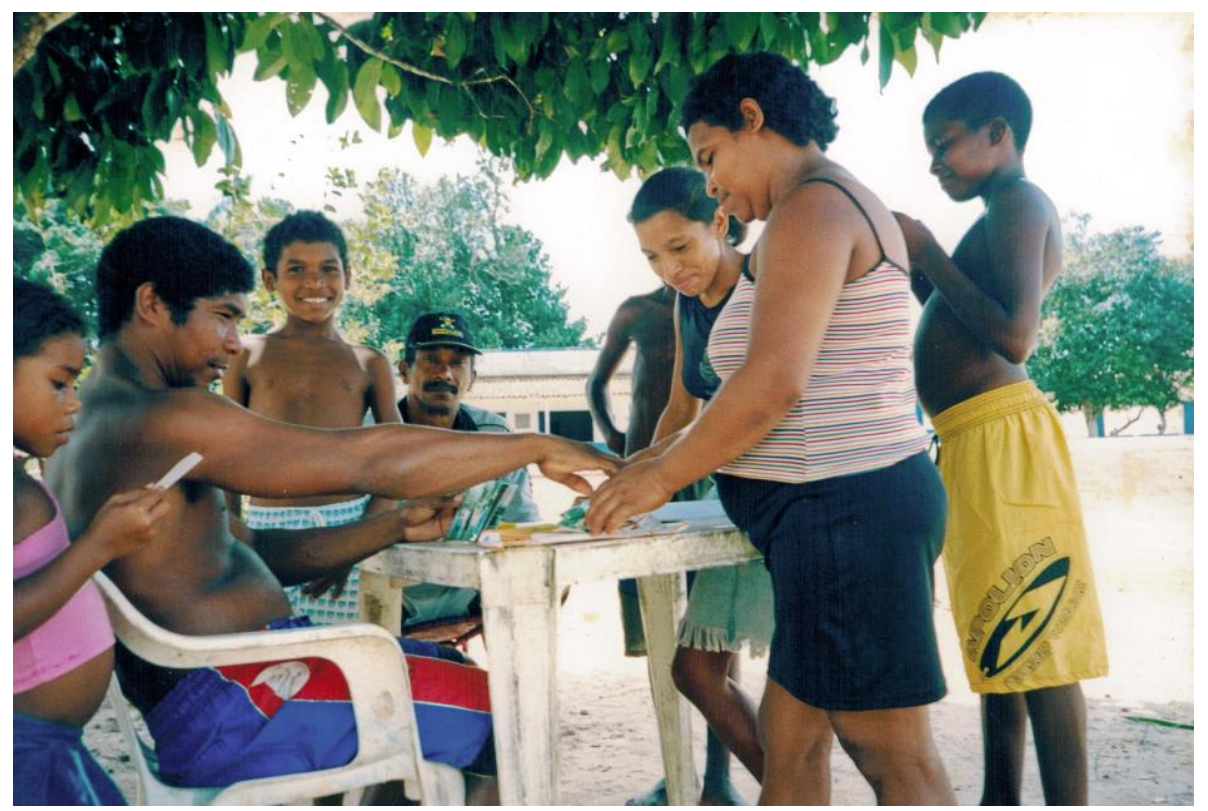

Fotografia 2 .

\section{As vantagens e desventuras de parecer com os nativos}

Les représentations construites sur le terrain ne naissent pas seulement de ce qui est donné à percevoir...le principe de la distinction primordiale qui permet d'identifier l'Autre comme différente de soi, pour pouvoir s'identifier soi-même. Mais, en anthropologie, il n'est jamais question de soi. De même qu'on ne raconte pas les effets corporels de son aventure, qu'on ne parle ni de ses maladies, ni de ses émotions, ni de ses sentiments, on est à peine consciente du fait que c'est de soi qu'il s'agit lorsqu'on s'en va ainsi regarder l'Autre sous le nez (Caratini, 2012: 5556)

Questões ligadas a nuances de tons de pele e fenótipo sempre me intrigaram por certamente terem a ver com minha própria aparência visto que na Amazônia sou considerada uma típica “morena café”. De forma que a temática de minha pesquisa está ligada a reflexões teóricas e intelectuais mas também a minha própria vivência enquanto negra. Por isso, minha própria imagem também foi problematizada em campo não apenas por mim, evidentemente, mas também pelos próprios interlocutores da pesquisa (ver fotografia 3).

Representações de cor da pele e aparência, terminologias étnico-raciais e reabilitação das mesmas como retórica política no contexto local dos povoados e em um contexto mais amplo da sociedade nacional. Enquanto questionava os informantes sobre esses assuntos, eles indagavam: "E tu te consideras como: negra ou branca?”, "Afinal, você é descendente de escravo ou não?”. Observei que em 2009 durante o período que 
estava em campo acompanhada de uma estudante de direito que me auxiliou a aplicar questionários a pergunta era endereçada a mim, jamais a ela. Por ser vista como branca, essa evidência visual não deixava margem de dúvidas.

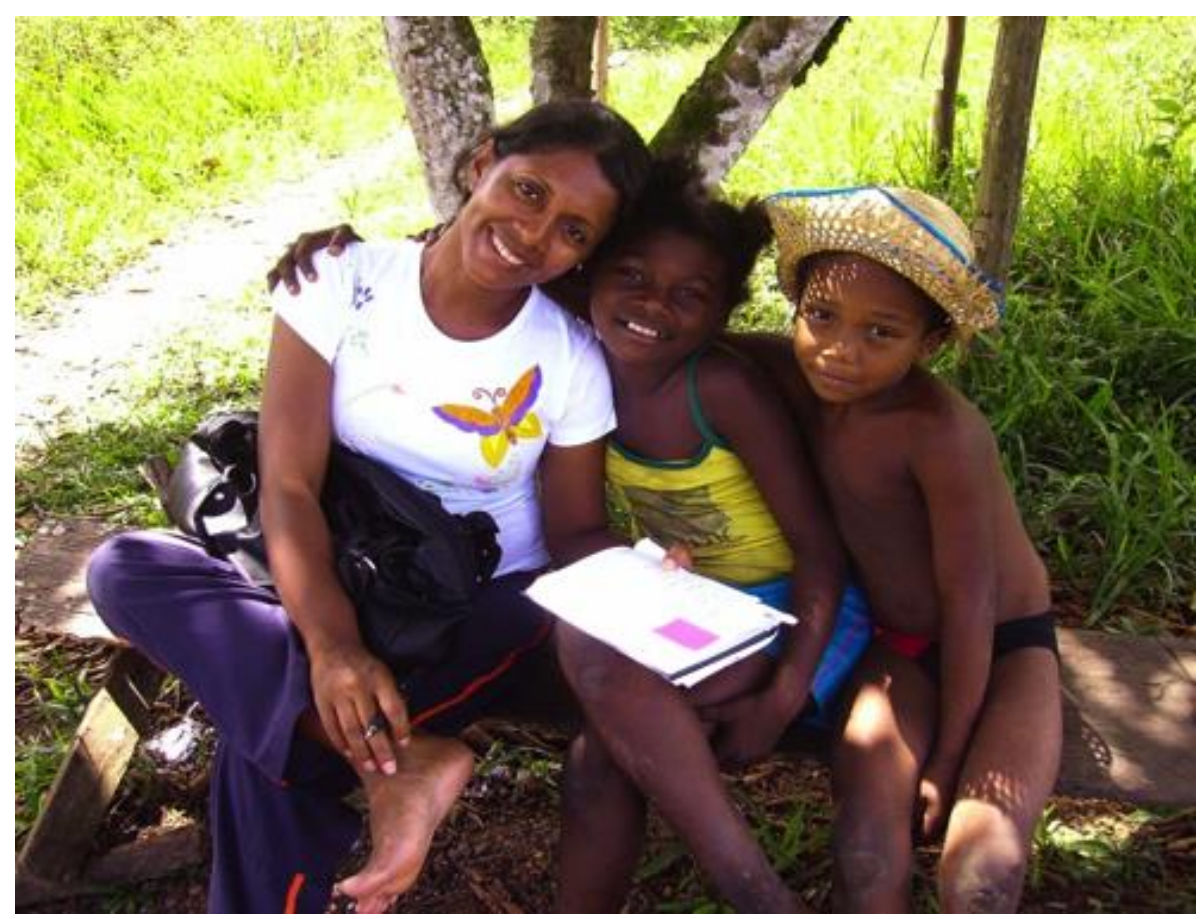

Fotografia 3.

Em Boa Vista, um dos interlocutores tentou fazer minha genealogia, remontando várias gerações de minha família para identificar precisamente quem foi o famoso escravo de quem herdei a pele preta. No caso, para ele para se autoconsiderar e ser considerado negro é preciso necessariamente ter tido um antepassado escravo na linhagem visto que, de acordo com sua percepção - que diz muito de uma percepção mais global - a cor da pele escura está associada diretamente a escravidão. Ora, como bem lembrou Godelier e Caratini (2012) enquanto classificamos, somos também classificados em um movimento recíproco.

Algumas vezes minha "identidade negra" aparecia em forma de constatação e servia para nos aproximar " tu que és negra como nós deve conhecer na pele o que é racismo e discriminação." No jogo da percepção e identificações, minha aparência e a deles se entrelaçavam, se entrecruzavam mostrando que se na vivência e cultura éramos diferentes, na aparência física não o éramos tanto assim. Candidatos políticos em campanha durante período eleitoral, me confundiram com uma das lideranças de Macapazinho, e pediram votos argumentando que iriam velar para que fossemos 
reconhecidos como "autênticos quilombolas". Tal acontecido virou motivo de graça ente mim e os moradores do vilarejo.

Ser parecida fisicamente com os interlocutores "abria algumas entradas", porém dificultava em alguns momentos, já que corria sérios riscos de ser confundida por eles, como uma das militantes do Movimento Negro. O que me levava ao dilema de como observar e me informar, ficando a parte de jogos políticos envolvendo agentes mediadores, não queria ser identificada com "o pessoal do racismo", tradução nativa dos ativistas do Movimento Negro em trânsito constante nos povoados, isso poderia fechar as portas a certas informações, o que acabou acontecendo em um momento ou outro. A definição que fizeram de mim se mostrou importante nas interações que se sucederam no espaço etnográfico.

Na minha volta a Macapazinho em 2009, em uma das primeiras visitas que fiz a família Simith, na hora da pausa do trabalho na casa de farinha, jovens adolescentes se puseram a folhear catálogos Avon, tecendo comentários sobre a aparência das modelos fotografadas, Luana, garota de 12 anos, suspirou exprimindo o desejo de ter um corte de cabelo igual a uma das modelos negras que identificou nas páginas do catálogo.

Indaguei qual penteado considerava bonito: a sua mãe, ela mostrou uma jovem com um penteado de longos cabelos alisados e a mim mostrou a mesma modelo com penteado diferente, com cabelos enrolados ou encaracolados. O gesto da adolescente que parecia estar envergonhada em revelar na minha presença seus ideais de beleza acabou gerando uma discussão entre sua mãe e sua tia. A mãe explicava que jamais deixaria a filha alisar os cabelos, nem com chapinha, nem com produtos. A tia da menina replicou que não sabia então como ela tinha deixado a prima da garota, que possuía uma prancha de alisar cabelos, alisar a franja dos cabelos da adolescente. Depois continuou me explicando que "a mulher do racismo de Belém" (militante do Movimento Negro) ficou chateada quando viu que as meninas do povoado estavam alisando os cabelos, após implantação de um salão de beleza na casa de uma das moradoras, e abandonando a prática de fazer trancinhas, aprendidas em uma oficina ofertada pelo Movimento, e que a mesma mostrou seus próprios cabelos dizendo que eram "duros", "duros", mas ela não os alisava e os aceitava como era. E mais uma vez tive que explicar minha presença ali e reforçar o fato que não era integrante do CEDENPA, salientando que enquanto pesquisadora não caberia a mim lhes dizer como deveriam se pentear, vestir ou viver. 
Além da aparência física, a noção de classe social, também acabou favorecendo a dinâmica de interação com alguns dos interlocutores da pesquisa. Diferentemente dos moradores de Macapazinho que vendem produtos agrícolas em frente à feira do mercado Ver-o-Peso em Belém, as famílias de Boa Vista vendem suas produções agrícolas na feira municipal do agricultor em Santa Isabel, no centro da cidade. Em um dos sábados que os acompanhei à feira, estávamos lá vendendo farinha de mandioca, quando meu pai que tem hábito de comprar e frequentar a feira passou por lá e me cumprimentou.

$\mathrm{Na}$ viagem da volta, dentro do caminhão da prefeitura municipal que nos levaria até o povoado, alguns homens se aglomeraram entorno de mim e veio a pergunta: “- De onde tu conheces aquele homem que te cumprimentou?" Quanta surpresa causou minha resposta quando expliquei que era meu pai. “- Como assim teu pai? Ele é pedreiro e é acostumado a tomar cachaça com a gente no mercado após a feira." Risadas e tapinhas nas costas, convites para ir a casa deles quando bem entendesse e quisesse não faltaram da parte dos presentes.

Narro esses fatos consciente que uma pessoa não precisa nem ser negra, nem ser filha de pobre para ter permissão de pesquisar nos povoados. Nem tenho como objetivo enfatizar minha dupla subalternidade (Spivak, 2009) ${ }^{6}$ ou inscrição específica, de cor e classe como privilégio, mas também não posso desconsiderá-la no contexto em que foi produzida a pesquisa. Sabe-se quão reduzida é a pluralidade racial, social e de classe nas universidades brasileiras (Pechincha, 2006), mesmo após a recente aplicação das cotas para estudantes negros e oriundos de escolas públicas sabe-se que a possibilidade de os interlocutores da pesquisa se defrontarem com uma pesquisadora negra, ainda é rara.

Enfatizo esse aspecto já que não posso negligenciar que se minha imagem enquanto negra (associada a pobre e sem nada a oferecer) dificultou minha entrada e retorno ao campo. Em um segundo momento quando "já estava lá” essa mesma imagem permitiu ricas interações entre mim e os interlocutores da pesquisa.

\footnotetext{
${ }^{6}$ Para Spivak os subalternos são, sobretudo, pessoas que têm suas palavras privada de condições necessárias à sua expressão e entendimento.
} 


\section{Conclusão}

Les photographies font parler. Elles peuvent même faire jaser. Elles sont également capables de susciter une double activité réflexive : d'acuité du regard, de réflexivité du sujet parlant et observant. Ce dernier peut tenter de dire ce que les images n'ont pas la possibilité de montrer (les sentiments), et celles-ci, de chercher à montrer ce qui résiste à être dit (la surface) (Laplantine, 2007: 53).

No presente texto procurei discutir o leque de interações e possibilidades provocadas em campo a partir da produção e circulação de imagens. Tentei, levando em consideração as reflexões de Laplantine (op.cit.), não apenas discutir as imagens em si, mas principalmente, a singularidade das relações que foram estabelecidas a partir delas na experiência etnográfica visto que como afirma o referido autor a fotografia não tem a capacidade de reproduzir o real mas de lhe transformar. O uso da câmera fotográfica possibilitou não apenas captar momentos fugazes de experiências cotidianas dos interlocutores da pesquisa mas também estreitar relações com eles. Houve um novo modo de conhecimento que se abriu quando a minha própria imagem foi também captada e questionada em campo. O que mostra que Laplantine está certo quando afirma que imagens podem assim posar ao lado da escrita na construção do conhecimento antropológico. 


\section{Referências}

ARRUTI, José Maurício. Mocambo: Antropologia e História do processo de formação quilombola. Bauru: Edusc, 2006.

BARLEY, Nigel. Un Anthropologue en déroute. Paris: Payot, 2001.

BECKER, Howard S. Sociologie visuelle, photographie documentaire et photojournalisme. Communications, v. 71, n. 1, p. 333- 351: 2001.

CARATINI, Sophie. Les non-dits de l'anthropologie suivi de Dialogue avec Maurice Godelier. Paris: Editions Thierry Marchaisse, 2012.

CLIFFORD, James. A experiência etnográfica: antropologia e literatura no século XX. Rio de Janeiro: Editora UFRJ, 2002.

COLLIER Jr., John. Antropologia visual: a fotografia como método de pesquisa. São Paulo: EDUSP, 1973 (1967).

CONORD, Sylvaine. Usages et fonctions de la photographie In Ethnologie Française, Tome XXXVII, p. 11-22, 2007/1.

BRASIL. Constituição Federal 1988. Brasília: Senado Federal, p.169, 1988.

GEERTZ, Clifford. O senso comum como sistema cultural. In: O saber local: novos ensaios em Antropologia Interpretativa. Petrópolis: Vozes, p. 111- 141, 1998.

GODELIER, Maurice e CARATINI, Sophie. Dialogue avec Maurice Godelier. In: Les non-dits de l'anthropologie. Paris: Editions Thierry Marchaisse, 2012.

LAPLANTINE, François. Penser en images. Ethnologie Française, v. 37, p. 47-56, 2007.

LEVI-STRAUSS, Claude. La pensée sauvage. Paris: Plon, 1962.

MALINOWSKI, Bronislaw. Les Argonautes du Pacifique occidental. Paris: Éditions Gallimard, 1989.

MARQUES, Olavo Ramalho. Entre a avenida Luís Guaranha e o quilombo do Areal: estudo etnográfico sobre memória, sociabilidade e territorialidade negra em Porto Alegre/RS. Dissertação de Mestrado em Antropologia, Porto Alegre: Universidade Federal do Rio Grande do Sul, 2006.

NOGUEIRA, Shirley e TRINDADE, Joseline. Macapazinho: história e memória dos negros do Itá. Projeto: Comunidades rurais negras do Pará, Belém, 2000.

NOVAES, Sylvia Caiuby. O uso da imagem na antropologia In: SAMAIN, Etienne (Org.). $O$ fotográfico. São Paulo, Hucitec e SENAC, 2005. Pp. 107-115.

PECHINCHA, Monica Soares. O Brasil no discurso da antropologia nacional. Goiânia: Cânone Editorial, 2006.

SILVA DA COSTA, Marcilene. Construire la légitimité quilombola en trois dimensions: phénotype, origine et lutte pour la terre. Tese de doutorado em Antropologia Social e Histórica. Toulouse: Universidade Toulouse II Jean Jaurès, 2015.

SILVA DA COSTA, Marcilene. Les actions affirmatives et la politique pour les habitants des communautés des descendants des esclaves de l'Amazonie brésilienne: In: BACOT, Jean-Pierre et ZONZON, Jacqueline (Org.). Guyane: Histoire et Mémoire : La Guyane au temps de l'esclavage, discours, pratiques et représentations, Actes du colloque du 16 au 18 nov 2010, Matoury, Ibis Rouge Editions, p. 381- 392, 2011.

SILVA, Vagner Gonçalves. O antropólogo e sua magia. São Paulo: Edusp, 2000.

SPIVAK, Gayatri Chakravorty. Les Subalternes peuvent-elles parler? Paris: Editions Amsterdam, 2009.

VELHO, Gilberto. Observando o familiar. In: NUNES, Edson de Oliveira (Org.). A aventura sociológica - objetividade, paixão, improviso e método na pesquisa social. Rio de Janeiro, Zahar, p. 37,1978.

VELHO, Gilberto. $O$ antropólogo pesquisando em sua cidade: sobre conhecimento e heresia. In: Gilberto Velho (Org.). O desafio da cidade. Rio de Janeiro: Campus, p. 13-21, 1980.

Recebido em: 02/11/2015.

Aprovado em: 14/03/2016. 